\title{
Proximate, Mineral Composition and Phytochemical Screening of Some Selected Spices of Ibadan Metropolis, Oyo State, Southwest, Nigeria
}

\author{
Adegbola Rachael Adebola ${ }^{1}$, Davies Caleb Adeosun ${ }^{2}$ and Abiona Dupe Lydia ${ }^{1}$ \\ 1. Chemistry Department, The Polytechnic, Ibadan, PMB 022, UIPO 21633, Oyo State, Nigeria \\ 2. National Horticultural Research Institute, PMB 5432 Idi-Ishin, Jericho, Ibadan 200261, Oyo State, Nigeria
}

\begin{abstract}
Spices which are widely used in Southwest Nigeria have aroma, enhance taste of food and possess medicinal values. Proximate, mineral composition and phytochemical screening of ten randomly selected spices were carried out. Recommended procedures were used for the analyses. Mineral composition was determined using flame photometer, colorimeter and (Atomic Absorption Spectrophotometer). The proximate composition showed that protein was high at $12.04 \%$ in Zingiber officinale and low at $2.1 \%$ in Xylopia aethiopica. Ocimium gratissium contained high moisture content at $82.1 \%$, while Tetrapleura tetraptera had the least value of $3.5 \%$. High ash content was recorded in Ocimum gratissium at $13.68 \%$ and lowest $0.98 \%$ in Allium cepa. For carbohydrate, Allium cepa had the highest value of 78.36\%, while Allium setiva had the least value of $19.48 \%$. Mineral composition showed high value of calcium $712 \mathrm{mg} / 100 \mathrm{~g}$, magnesium $172.2 \mathrm{mg} / 100 \mathrm{~g}$, potassium $868.5 \mathrm{mg} / 100 \mathrm{~g}$, sodium $75.85 \mathrm{mg} / 100 \mathrm{~g}$, and manganese $95.38 \mathrm{mg} / 100 \mathrm{~g}$ in Allium sativa, Xylopia aethiopica, Momodara myristica, Ocimum gratissimum, Tetrapleura tetraptera respectively. Aframomium meleghueta had high value of iron and zinc at $85 \mathrm{mg} / 100 \mathrm{~g}$ and $97 \mathrm{mg} / 100 \mathrm{~g}$ respectively and also high presence of alkaloids, glycosides, saponins and tannis. High values of saponins and triterpenoids were observed in Zingiber officinale and Ocimum gratissimum respectively. This study showed that spices have greater use in medicine and as food supplement.
\end{abstract}

Key words: Spices, phytochemical screening, proximate, mineral composition.

\section{Introduction}

Spices refer to all of the edible parts of a plant including fruit, seed, root, rhizomes, barks, leaves, flowers and any other vegetative substances used in a very small quantity as food additives to colour, flavour or preserve food [1, 2]. Spices have many other uses like medicinal, religious ritual, cosmetics or perfume production, or as a vegetable (Kadam et al., 2015). Spices have nutritional value and are often referred to as food accessories or adjuncts because of their ability to stimulate appetite and increase the flow of gastric juice. Spices are a large group of such natural ingredients, and include dried seeds, fruits, roots (Birt, 2006). Spices are fragrant, aromatic and pleasant.

Corresponding author: Adegbola Rachael Adebola, masters, main research field: natural product chemistry.
Phytochemicals are plant metabolites (Sofowurra, 1993) which act as natural defence systems for host plants, and also provide characteristic colour, aroma and flavour in specific plant parts. They are a group of non-nutrient compounds that are biologically active when consumed by human. Many phytochemicals are health-promoting and are of many disease preventive (Rowland, 1999; Birt, 2006). Both epidemiological and clinical studies have proven that phytochemicals present in cereals, fruits and vegetables are mainly responsible for reduced incidence of chronic and degenerative diseases among populations whose diets are high in these foods (Shahidi, 1996).

According to WHO (World Health Organization), more than $80 \%$ of the world's population relies on traditional medicines for their primary health care needs. The medicinal value of spices, which include leaves, buds, bulbs, fruits, stem, rhizomes, bark and 
other plant parts, has been defined as plant substances from indigenous or exotic origin, aromatic or with strong taste, used to enhance the taste of foods. Herbs and spices have been used during the middle ages for flavoring, food preservation, and/or medicinal purposes. Only a small percentage of plants species have been investigated phytochemically and the fraction submitted to biological screening is even smaller (Harsha et al., 2013). The medicinal value of plants lies in some chemical substances that have a definite physiological action on the human body. Different phytochemicals have been found to possess a wide range of activities, which may help in protection against chronic diseases.

There is dearth of information on most indigenous Nigerian spices and this limits their use internationally as preservatives and functional ingredients. It is therefore necessary to evaluate proximate, mineral composition and phytochemical screening of some selected spices of Ibadan Metropolis, Oyo State, Southwest, Nigeria, namely Aframomum melegueta, Allium cepa, Allium sativa, Capsicum annuum, Ocimum gratissium, Syzygium aromaticum, Zingiber officinale, Xylopia aethiopica, Monodora myristica and Tetrapleura tetraptera to diversify their use as natural preservatives and as culinary spices that contain active ingredients that promote health and reduce the risk of disease.

The paucity of knowledge of the proximate, mineral composition and phytochemical constituents of these indigenous spices has resulted in their neglect and underutilization. It is envisaged that the result of this study will initiate the exploitation of the preservative, nutraceutical and therapeutic potentials of these culinary spices.

Therefore, this study will provide detailed information on proximate, mineral composition and phytochemical constituents of these ten spices for broader application in foods and other relevant areas. It would attract international recognitions that can earn Nigeria huge revenue. This would create employment for many Nigerians who would propagate and process the spices.

\section{Aims and Objectives}

The aims of this study were to evaluate proximate, mineral composition of ten popular local Nigerian spices for food preservation and promotion of good health.

\section{Specific Objectives}

The specific objectives of this research work include the following:

(1) To determine the proximate composition of the selected spices.

(2) To determine the mineral composition of the selected spices.

(3) To check the phytochemical screening of all the selected spices.

(4) To make recommendation based on the result.

\section{Results}

The results were presented below:

From Fig. 1 the highest moisture content was observed in Ocimum gratissimum, Aframomum melgueta showed lowest total fat content, protein was highest in Monodora myristica, Allium cepa showed highest carbohydrate content while tetrapleura tetraptera showed lowest content. Fatty acid was highest in Zingiber officinale. Ash content was highest in Ocimum gratissimum shown.

Table 1 showed high contents of calcium in most of the spices analysed. Higher values of magnesium $172.20 \mathrm{mg} / 100 \mathrm{~g}$ were observed in Xylopia aethiopica. Monodora myristica had higher value of potassium $868.5 \mathrm{mg} / 100 \mathrm{~g}$. Iron and zinc content was high in Aframomum meleguata.

Table 2 showed that Aframomum melegueta and Zingiber officinale possessed very high levels of alkaloids. Monodora myristica had higher glycosides, saponins and tannis. Ocimum gratissimum and Zingiber officinale had higher triterpenoids and saponnis, respectively. 


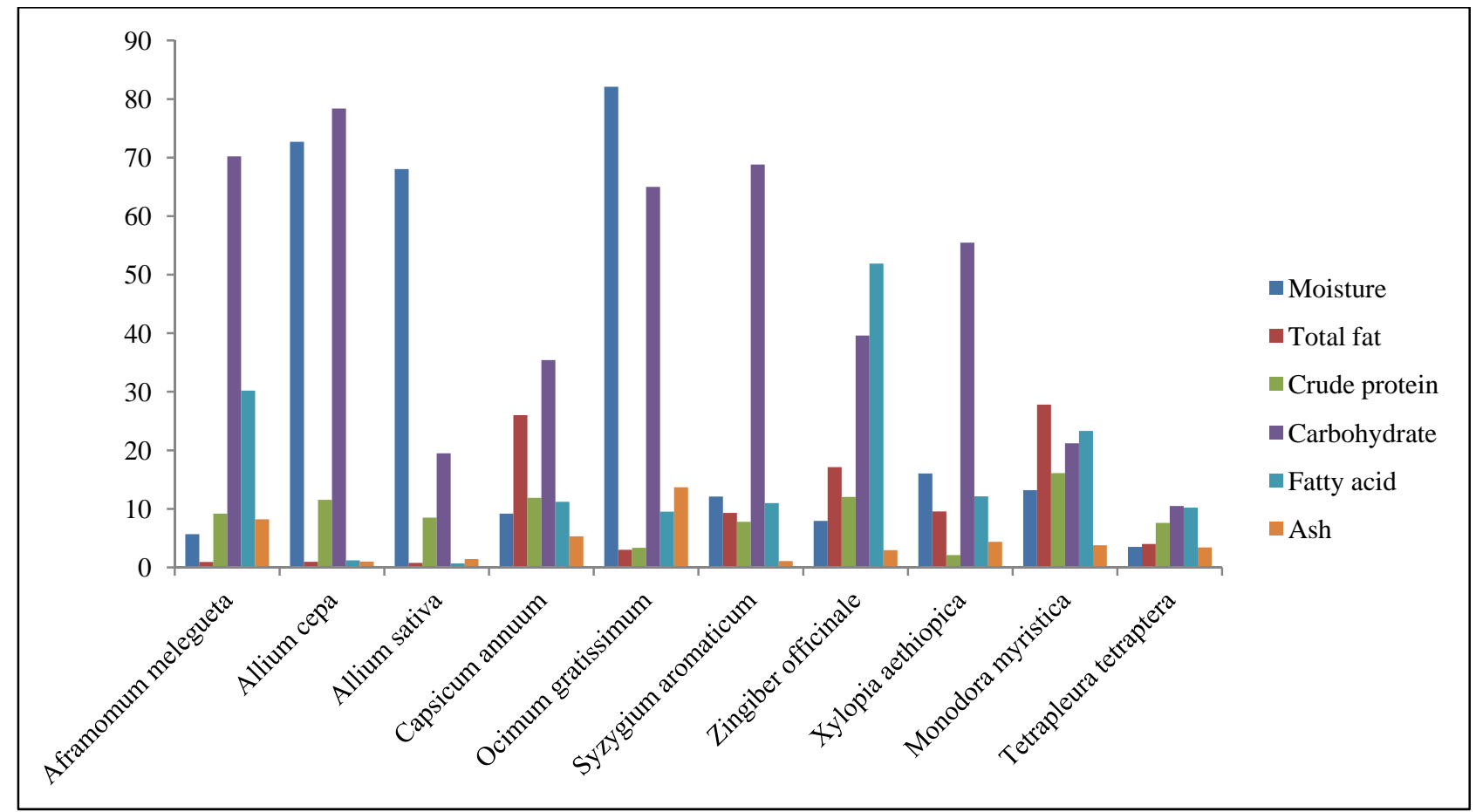

Fig. 1 Proximate composition in percentage.

Table 1 Mineral Composition of the spices in $\mathbf{m g} / \mathbf{1 0 0 g}$.

\begin{tabular}{llllllll}
\hline Specimen & Calcium & Magnesium & Potassium & Sodium & Manganese & Iron & Zinc \\
\hline Aframomum melegueta & 2.5 & 0.82 & 0.54 & 0.21 & 0.14 & 85 & 97 \\
Allium cepa & 46.95 & 70.99 & 140.3 & 3.66 & 0.62 & 0.6 & 0.2 \\
Allium sativa & 712 & 101 & 1500 & 49 & 2 & 30 & 1.9 \\
Capsicum annuum & 27.2 & 8.7 & 1.7 & 13.8 & 0.8 & 9.6 & 3.6 \\
Ocimum gratissimum & 5.20 & 0.53 & 1479 & 75.85 & 7.66 & 13.84 & 12.84 \\
Syzygium aromaticum & 3.44 & 0.87 & 21 & 3.24 & 7.42 & 20.11 & 1.22 \\
Zingiber officinale & 0.92 & 1.20 & 4.97 & 60.34 & 7.33 & 80.2 & 12.22 \\
Xylopia aethiopica & 228.00 & 172.2 & 277.34 & 17.31 & 11.30 & 34.7 & 3.84 \\
Monodora myristica & 416.1 & 86.8 & 868.5 & 17.7 & 1.1 & 21.74 & 1.52 \\
Tetrapleura tetraptera & 1.56 & 2.60 & 7.84 & 4.92 & 95.38 & 12.04 & 10.68 \\
\hline
\end{tabular}

Table 2 Phytochemicals screening of the spices.

\begin{tabular}{|c|c|c|c|c|c|c|c|c|}
\hline Specimen & Alkaloid & Anthraquinones & Flavonoids & Glycosides & Saponins & Steroids & Tannis & Triterpenoid \\
\hline Aframomum melegueta & +++ & - & ++ & +++ & - & +++ & - & ++ \\
\hline Allium сера & + & + & + & + & + & - & - & + \\
\hline Allium sativa & + & + & + & + & + & + & - & + \\
\hline Capsicum annuum & - & - & + & + & + & + & - & + \\
\hline Ocimum gratissimum & - & - & + & ++ & + & + & ++ & +++ \\
\hline Syzygium aromaticum & + & - & + & + & + & ++ & ++ & ++ \\
\hline Zingiber officinale & +++ & + & + & ++ & +++ & - & ++ & + \\
\hline Xylopia aethiopica & - & - & ++ & + & + & + & - & + \\
\hline Monodora myristica & ++ & - & ++ & +++ & +++ & - & +++ & ++ \\
\hline Tetrapleura tetraptera & + & - & + & ++ & ++ & + & - & + \\
\hline
\end{tabular}

Legend: Nil-Slightly present + -Moderately present ++ - Highly present +++ . 


\section{Discussion}

Proximate composition of the spices shows that $A$. sativa, T. tetraptera and M. monodora have low percentage of carbohydrate, which makes them good spices for diabetic patients. Proteins and carbohydrates are necessary for the repair and maintaining the animal body.

O. gratissimum, A. cepa and A. sativa have highest moisture contents. High total fats were recorded in $M$. myristica, C. annuum and Z. officinale. Fatty acid was high in Z. officinale, A. melegueta, and M. myristica. O. gratissimum and $A$. melegueta showed high value of ash.

The present study showed that Aframomum melegueta and Zingiber officinale possessed very high levels of alkaloids. Monodora myristica had higher glycosides, saponins and tannins. Ocimum gratissimum and Zingiber officinale had higher triterpenoids and saponnis respectively. The spices are rich sources of phytocompounds which can be used in the synthesis of drugs that can be used to prevent or treat various diseases. The work agrees with the findings of Kadam et al., 2015 in the analysis of some Indian spices. Researchers (Kadam et al., 2015; Rao and Kumara, 2014; Otunola et al., 2010; Okwu, 2001) had reported that the phytocompounds can be used as antioxidants, in allopathic systems, cytotoxicity, anti-carcinogen, anti-inflammation, cardiovascular protection, cell proliferation activities, lowering blood pressure, treatment of congestive heart failure and cardiac arrhythmia, anti-allergic, anti-tumoral activity anti-inflammatory, anti-microbial activities (Shreya et al., 2015), treatment of cough, asthma and hay fever due to the possession of important biological activities.

Spices are good sources of nutrients, mineral elements that can be used as nutritional supplements. This was confirmed by this present work that shows the presence of calcium, magnesium, potassium, sodium, manganese, iron and zinc at appreciable levels in all the spices analysed. High concentration of calcium was reported in most of the spices analysed. Calcium is the mineral responsible for the development of bones. Higher value of magnesium $172.20 \mathrm{mg} / 100 \mathrm{~g}$ was observed in $X$. aethiopica, $M$. myristica had higher value of potassium 868.5 mg/100g. Iron and zinc content was high in A. meleguata. The values obtained were in agreement with the work of Boubs et al., 2012 in their study of Camerron spices of M. myristica, T. tetraptera and X. aethiopica but iron and zinc concentrations were lower in $T$. tetraptera while only manganese value was lower in $X$. aethiopica. It was collaborated with the work of Otunola et al., 2010 that reported the presence of mineral elements such as calcium, iron, potassium, phosphorus, sodium, magnesium, copper and zinc, which are very important to human nutrition.

\section{Conclusion}

From the results of the analyses, it can be concluded that the spices analysed possess phytochemicals, mineral elements and proximate components that make them good sources of active ingredients for drugs and nutritional supplements.

\section{Recommendation}

It is therefore recommended that these spices therapeutic potentials should be exploited, and that they should be used in food fortification and as food supplements.

\section{References}

[1] Birt, D. A. 2006. "Phytochemicals and Cancer Prevention: From Epidemiology to Mechanism of Action.” Journal of the American Dietetic Association 106 (197): 20-4.

[2] Bouba, A. A., Njintang, N. Y., Foyet, H. S., Scher, J., Montet, D., and Mbofung, C. M. F 2012. "Proximate Composition, Mineral and Vitamin Content of Some Wild Plants Used as Spices in Cameroon.” Food and Nutrition Sciences 3: 423-32.

[3] Harsha, N., Sridevi, V., Chandana, L. M. V. V., Rani, K, N., and Vani, D. S. 2013. "Phytochemical Analysis of 

Ibadan Metropolis, Oyo State, Southwest, Nigeria

Some Selected Spices.” International Journal of Innovative Research in Science, Engineering and Technology 2 (11): 6619-21.

[4] Ross, J., and Kasum, C. 2002. "Dietary Flavonoids: Bioavailability, Metabolic Effects and Safety.” American Review on Nutrition 22: 19-34.

[5] Rowland, I. 1999. "Optimal Nutrition: Fibre and Phytochemicals.” Proceedings of Nutrition Society 58: 415-9.

[6] Shreya, A., Manisha, D., and Sonali, M. 2015. "Phytochemical Screening and Anti-microbial Activity of Cinnamon species against Urinary Tract Infection and Fungal Pathogens.” International Journal of Life Science \& Pharma Research 5 (4): 30-8.

[7] Otunola, G. A., Oloyede, O. B., Oladiji, A. T., and Afolayan, A. J. 2010. "Comparative Analysis of the Chemical Composition of Three Spices -Allium Sativum,
Zingiber officinale, Rosc and Capsicum Frutescens L. Commonly Consumed in Nigeria." Africa Journal of Brotechnology 9 (41): 6927-31.

[8] Okwu, D. E. 2001. "Evaluation of the Chemical Composition of Medicinal Plants Belonging to Euphorbiaceae.” Pak Veterianary Journal 14: 160-2.

[9] Sofowora, L. A. 1993. Medicinal Plants and Traditional Medicine in Africa. Ibadan: Spectrum Book Ltd., pp. 55-71.

[10] Kadam, D. D., Mane, P. C., and Chaudhari, R. D. 2015. "Phytochemical Screening and Pharmacological Applications of Some Selected Indian Spices." International Journal of Science and Research 4 (3): 704-6.

[11] Shahidi, F., and Naczk, M. 2004. Antixidant Properties of Food Phenolics. In:. Phenolics in Food and Nutraceuticals. Boca Raton, Fla.: CRC Press, pp. 1, 403. 